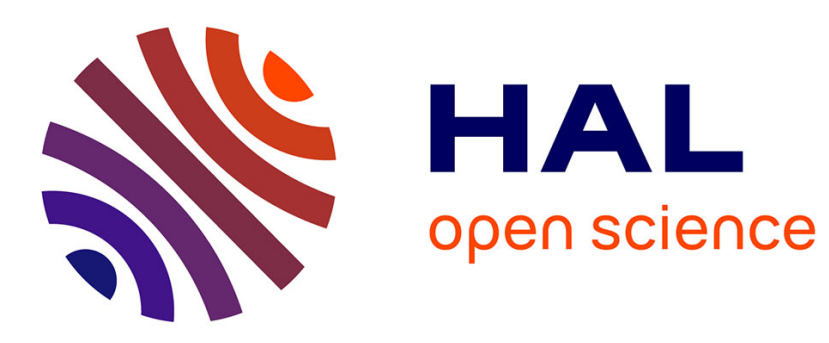

\title{
Atmospheric reactions of 9,10-anthraquinone
}

Killian Miet, Alexandre Albinet, Hélène Budzinski, Eric Villenave

\section{To cite this version:}

Killian Miet, Alexandre Albinet, Hélène Budzinski, Eric Villenave. Atmospheric reactions of 9,10anthraquinone. Chemosphere, 2014, 107, pp.1-6. 10.1016/j.chemosphere.2014.02.050 . ineris01710231

\section{HAL Id: ineris-01710231 \\ https://hal-ineris.archives-ouvertes.fr/ineris-01710231}

Submitted on 15 Feb 2018

HAL is a multi-disciplinary open access archive for the deposit and dissemination of scientific research documents, whether they are published or not. The documents may come from teaching and research institutions in France or abroad, or from public or private research centers.
L'archive ouverte pluridisciplinaire $\mathbf{H A L}$, est destinée au dépôt et à la diffusion de documents scientifiques de niveau recherche, publiés ou non, émanant des établissements d'enseignement et de recherche français ou étrangers, des laboratoires publics ou privés. 


\title{
Atmospheric Reactions of 9,10-Anthraquinone
}

\author{
Killian Miet, ${ }^{1,2}$ Alexandre Albinet, ${ }^{3}$ Hélène Budzinski, ${ }^{1,2}$ Eric Villenave ${ }^{1,2} *$ \\ ${ }^{1}$ Univ. Bordeaux, EPOC, UMR 5805, F-33405 Talence cedex, France \\ ${ }^{2}$ CNRS, EPOC, UMR 5805, F-33405 Talence cedex, France \\ ${ }^{3}$ Institut National de l'Environnement Industriel et des RISques (INERIS), Parc Technologique Alata, \\ BP2, 60550 Verneuil en Halatte, France
}

*Corresponding author: E-mail address: eric.villenave@u-bordeaux.fr

\begin{abstract}
The probably carcinogenic compound 9,10-anthraquinone is mainly existing in the atmosphere in the particulate phase and is often detected and measured among other oxygenated PAHs in atmospheric samples. Its fate, once released or formed in the atmosphere, still remains unknown. In this work, heterogeneous chemical oxidation processes of 9,10-anthraquinone were investigated with ozone $\left(\mathrm{O}_{3}\right)$, nitrogen dioxide $\left(\mathrm{NO}_{2}\right)$ and hydroxyl radical $(\mathrm{OH})$. The study of 9,10-anthraquinone adsorbed on silica particles showed no reactivity with $\mathrm{O}_{3}$ and $\mathrm{NO}_{2}$. On the other hand, the reaction with $\mathrm{OH}$ radicals was observed and led to the formation of 1-hydroxy-9,10-anthraquinone, another oxidation product recognized as possibly carcinogenic to humans. This study showed that reactions with ozone and nitrogen dioxide are unlikely to contribute to atmospheric degradation of 9,10 anthraquinone, whereas reactions with $\mathrm{OH}$ radicals could be involved in 9,10-anthraquinone degradation processes, even if such reaction is probably very slow under ambient conditions.
\end{abstract}


Keywords: 9,10-anthraquinone; Hydroxyl radical; Ozone; Nitrogen dioxide; Kinetics; 1hydroxy-9,10-anthraquinone

\section{Introduction}

Polycyclic aromatic hydrocarbons (PAHs) and their derivatives are organic compounds widely distributed in the environment. They are mainly emitted into the atmosphere as byproducts of organic matter and fossil fuel incomplete combustion (domestic heating, automobile fuel combustion, wood burning...). For the most part, PAHs have an anthropogenic origin in the atmosphere and once emitted, they are present in both, gaseous form and adsorbed to particles, depending on the volatility of the PAH species. Low molecular weight compounds exist mainly in the gas phase, whereas PAHs bearing five fused rings or more are predominately adsorbed onto particulate matter (Odabasi et al., 1999; Callén et al., 2008; (Albinet et al., 2008)).

PAHs have been extensively studied in the gas phase and adsorbed to particles with atmospheric oxidants (Pitts et al., 1985; Estève et al., 2004; Perraudin et al., 2005 and 2007a; Atkinson and Arey, 2007; Gross and Bertram, 2008; Miet et al., 2009a and 2009b). Concerning oxidation products, which seem more toxic than the parent compounds ((Durant et al., 1996; Durant et al., 1998; Pedersen et al., 2004; Pedersen et al., 2005)), there is a lack of data concerning their fate. Nitrated and oxygenated PAHs are often detected in ambient air samples (Castells et al., 2003; Albinet et al., 2007; (Albinet et al., 2008; Ringuet et al., 2012a)) as compounds directly emitted during combustion processes or as oxidation products formed in the atmosphere by photolysis and reaction of PAHs with oxidants $\left(\mathrm{NO}_{\mathrm{x}}, \mathrm{OH}, \mathrm{O}_{3}\right.$, $\mathrm{SO}_{\mathrm{x}}$ ). Among such compounds, quinones are often detected in atmospheric aerosol samples (König et al., 1983; Lewis et al., 1995; Allen et al., 1997; Cho et al., 2004; Shimmo et al., 
2004; del Rosario Sienra and Rosazza, 2006; Jakober et al., 2006; Albinet et al., 2007; Andreou et al., 2009; (Albinet et al., 2008; Ringuet et al., 2012a)) and are suspected to contribute to the toxicity of ambient particles. Their toxic effects are often attributed to their ability to form reactive oxygen species (ROS) (Lemaire and Livingstone, 1997; Kumagai and Shimojo, 2001), but also for their mutagenicity (Chesis et al., 1984; Durant et al., 1996; (Pedersen et al., 2004; Pedersen et al., 2005)). Recently, the IARC has classified 9,10anthraquinone as a group $2 \mathrm{~B}$ chemical, signifying its carcinogenic probability to humans ((IARC, 2012)) and highlighting the study of the fate of this compound.

The formation of quinones has been highlighted in some works as oxidation products from PAHs by photolysis or reactions with $\mathrm{O}_{3}, \mathrm{NO}_{3}$ and $\mathrm{OH}$ (Helmig and Harger, 1994; Dabestani et al., 1995; Barbas et al., 1996; Mallakin et al., 2000; Kwamena et al., 2006; Perraudin et al., 2007b; Wang et al., 2007; Yu, 2002; Vione et al., 2004), leading to the formation of compounds such as 9,10-phenanthrenequinone or 9,10-anthraquinone. Despite its high concentration levels observed in ambient air, very few works investigated the fate of 9,10-anthraquinone whatever the degradation pathway.

In this work, the heterogeneous reactivity of 9,10-anthraquinone was investigated with three oxidants of tropospheric interest $\left(\mathrm{O}_{3}, \mathrm{NO}_{2}\right.$ and $\left.\mathrm{OH}\right) .9,10$-Anthraquinone was coated on silica particles as a model for mineral particles. Atmospheric particulate matter constitutes a complex medium and silica, which constitutes an important fraction of mineral particles, allows to simplify the solid substrate (Harrison and Yin, 2000; Rodriguez et al., 2008) in order to obtain better reproductility in kinetic measurements. This kind of particle has been used in previous studies (Behymer and Hites, 1985; Alebic-Juretic et al., 1990; Barbas et al., 1996; Wang et al., 1999; Perraudin et al., 2005 and 2007a; Miet et al., 2009a and 2009b), showing that such particles constitute a good model in order to investigate heterogeneous reaction processes. 


\section{Experimental}

\subsection{Preparation of the particles}

Silica particles IT70-5 were supplied by Interchim. According to their certificate of analysis, the silica particles have an average particle diameter of $5 \mu \mathrm{m}$ and an average pore diameter of $70 \AA$. Their specific surface area is about $500 \mathrm{~m}^{2} \mathrm{~g}^{-1}$. The diameter of these particles is situated in the coarse particle mode. These particles have well-defined properties already detailed in a previous work by Perraudin et al. (2005).

Silica particles were first cleaned by ultrasonication using dichloromethane (HPLC grade, Acros Organics). After drying, the particles were introduced in a solution of dichloromethane containing 9,10-anthraquinone (97\%, Aldrich). The solvent was then evaporated using a rotary evaporator (at atmospheric pressure and $\mathrm{T}=35^{\circ} \mathrm{C}$ ). Coated particles were finally stored in amber glass flasks at ambient temperature until reactivity experiments.

\subsection{Analytical procedures}

After the addition of a surrogate standard (fluoranthene-d10, 99.2 \%, MSD isotopes), coated particles were extracted using pressurized fluid extraction ( $\operatorname{ASE}^{\circledR}$ 200, Dionex) with dichloromethane $\left(\mathrm{P}=100\right.$ bars, $\mathrm{T}=100{ }^{\circ} \mathrm{C}$, heat time of $5 \mathrm{~min}$ and 2 static extraction cycles of 8 min). Extracts were then evaporated in the ASE extract-collecting flask and changed to isooctane (HPLC Grade, Scharlau) using a vacuum evaporation system (Rapidvap, Labconco), with the following parameters: $70 \%, 900 \mathrm{mbar}, 50{ }^{\circ} \mathrm{C}$ during $20 \mathrm{~min}$. 
After the addition of a internal standard (pyrene-d10, 98\%, MSD isotopes) (used to quantify surrogate standard), samples were analysed by gas chromatography (HP model series 6890 Gas Chromatograph, Agilent Technologies) coupled to mass spectrometry (HP model 5973 mass selective detector, Agilent Technologies), using a HP-5MS capillary column (30 m $\times 0.25 \mathrm{~mm}$ ID $\times 0.25 \mu \mathrm{m}$ film thickness, Hewlett Packard). The temperature program was 70 ${ }^{\circ} \mathrm{C}$ during 2 min up to $300{ }^{\circ} \mathrm{C}$ at a rate of $10{ }^{\circ} \mathrm{C} \min ^{-1}$ and held at $300{ }^{\circ} \mathrm{C}$ during $5 \mathrm{~min}$. The carrier gas was helium (He 99.9999+ \% purity, Linde Gas) at a constant flow rate of $1 \mathrm{~mL}$ $\min ^{-1}$. The interface temperature was kept at $280^{\circ} \mathrm{C}$ during analysis. The mass spectrometer was operating under electron impact ionisation $(70 \mathrm{eV})$ and mass detection was carried out in selected ion monitoring $(\mathrm{SIM})$ mode $($ dwell time $=100 \mathrm{~ms}$, number of cycles per second $=$ 1.16 and electron multiplier voltage $=(2400 \pm 50) \mathrm{V})$.

The analysis performed by GC-MS allowed to evaluate the initial 9,10-anthraquinone particulate concentration: $(592 \pm 27) \mu \mathrm{g} \mathrm{g}^{-1}$ of silica $(\mathrm{n}=22)$. Extraction efficiencies were also determined using the surrogate standard recovery yield, obtained from its quantification related to pyrene-d10 $(98 \pm 3) \%(\mathrm{n}=22)$. This value, close to $100 \%$, shows that 9,10 anthraquinone extraction from silica particles is very efficient.

\subsection{Experimental reaction setups}

All experiments were performed in a total darkness to avoid any photodegradation and to only account for the 9,10-anthraquinone degradation in the reactors. 9,10-Anthraquinone oxidation was followed by measuring the remaining concentration present on silica particles versus oxidant exposure time.

\subsubsection{Ozone setup}


The ozone setup used in this study was developed in our laboratory by Perraudin et al. (2007a). It consists of a photolysis cell in which a mixture of nitrogen and oxygen is introduced and photolysed at $185 \mathrm{~nm}$ by a low pressure mercury lamp (NIQ 120/80, Heraeus SAS). The ozone concentration was controlled by varying the oxygen ratio (total flow constant at $3 \mathrm{~L} \mathrm{~min}^{-1}$ ), and the distance between the photolysis cell and the lamp. The $\mathrm{N}_{2} / \mathrm{O}_{2} / \mathrm{O}_{3}$ flow was then directed to the reactor in which a filter, with the coated particles, was placed. The output of the reaction cell was directed to the $\mathrm{O}_{3}$ measurement cell $(41.5 \mathrm{~cm}$ long), in which $\mathrm{O}_{3}$ concentration was measured by its well-known absorption at $254 \mathrm{~nm}$, the irradiation being emitted from a deuterium lamp (L7296, Hamamatsu Photonics). The monochromator (Jobin Yvon) wavelength was regularly calibrated using a low-pressure mercury lamp.

\subsection{2. $\mathrm{OH}$ and $\mathrm{NO}_{2}$ setup}

The $\mathrm{OH}$ and $\mathrm{NO}_{2}$ experimental setup was similar to that previously used in our laboratory to study heterogeneous reactivity (Estève et al., 2003 and 2004; Miet et al., 2009c, (Ringuet et al., 2012b)). It consists of a fast flow-tube reactor $(2.4 \mathrm{~cm}$ inside diameter / $48 \mathrm{~cm}$ long Pyrex tube) in which a movable injector ( $1 \mathrm{~cm}$ inside diameter, $60 \mathrm{~cm}$ long quartz tube) slides. Gases were introduced in the main reactor through the injector, which was wall-coated inside with halocarbon wax (Halocarbon Products Corporation, series 1500) in order to minimize heterogeneous recombination on the walls. The reactor pressure was regulated by a two-stage primary pump (Alcatel T2060) and monitored with a capacitance gauge (Edwards Barocel 600, 0 - 10 Torr). Total pressure was held at $(1.8 \pm 0.1)$ Torr during all experiments. Total 
flow in the reactor was approximately $1 \mathrm{~L} \mathrm{~min}^{-1}$ and was laminar in all experiments based on the Reynolds number.

$\mathrm{NO}_{2}$ concentration was controlled by dilution of $\mathrm{NO}_{2}\left(5 \% \mathrm{NO}_{2}\right.$ in Helium $99.995 \%$ purity, Alphagaz, Air liquide) in helium (Alphagaz 1, Air liquide) using calibrated mass flow controllers (FC260 and FC2900 Mykrolis).

$\mathrm{OH}$ radicals were generated in situ at the upstream of the movable injector by the fast reaction between nitrogen dioxide and a hydrogen atom, produced by hydrogen impurities from helium (Alphagaz 1, Air liquide), the main carrier gas, passing through an $80 \mathrm{~W}$ microwave discharge (Raitek LRE 300, $2450 \mathrm{MHz}$ ). $\mathrm{NO}_{2}$ concentration was used in excess and held at $2.7 \times 10^{13}$ molecules $\mathrm{cm}^{-3}$ during experiments, in order to convert stoichiometrically all $\mathrm{H}$ atoms into $\mathrm{OH}$ radicals.

$\mathrm{OH}$ formation was controlled by light induced fluorescence (LIF) using the $\mathrm{A}^{2} \Sigma^{+} \leftarrow \mathrm{X}^{2} \Pi$ transition. The radical excitation, by a dye laser (Quantel TLV IV) pumped by a Nd:YAG laser (Quantel YG 481C) system, was performed at $282 \mathrm{~nm}$. The resulting fluorescence, at 314 and $309 \mathrm{~nm}$ was focused with a biconvex lens on a photomultiplier after being filtered with an interferential filter (Oriel 5703: $(310 \pm 10) \mathrm{nm})$. The signal was monitored using an oscilloscope (Tektronix 2439).

\subsubsection{Experimental procedures}

About $5 \mathrm{mg}$ of coated particles were placed with a sieve $(45 \mathrm{~mm}$ diameter, $100 \mu \mathrm{m}$, Sigma-Aldrich) on a glass fibre filter $(\mathrm{QF} / \mathrm{F}, 47 \mathrm{~mm}$ diameter, Whatman) previously cleaned by ultrasonication in dichloromethane and heated at $723 \mathrm{~K}$. Particles were weighted before and after reaction (TR-64, Denver Instrument Company, $0.01 \mathrm{mg}$ precision). 
For each experiment, the kinetic information was obtained by monitoring the remaining concentration of 9,10-anthraquinone versus exposure time to oxidant. Concentrations vs. time were normalised, i.e. the PAH concentration measured in $\mu \mathrm{g} \mathrm{g}^{-1}$ of particles after an exposure time $t$ was divided by the corresponding initial particulate-PAH concentration (measured at $t$ $=0$ ), leading to a normalised particulate concentration of compound in $\%$.

\subsection{Uncertainties}

Errors on internal and syringe standards weighting, on silica particles weighting, on chromatographic peak integration and on GC/MS measurements were considered as random errors. Total random error was estimated by the standard deviation on the exponential coefficients obtained from the non-linear least square fit of the experimental points, and was less than $25 \%$ for all experiments. Systematic errors (oxidant concentration, pressure, temperature, and calibration of mass flow controllers) were also taken into account. Finally, global uncertainties (random + systematic) on pseudo-first order rate constants were evaluated around $35 \%$.

\section{Results and discussion}

\subsection{Desorption}

The desorption study is very important to ensure that 9,10-anthraquinone losses are only due to reactions with oxidants. Experiments were performed in the same conditions than those used to oxidation reactions but without $\mathrm{O}_{3}$ for the ozone setup and without $\mathrm{NO}_{2}$ and $\mathrm{OH}$ for the fast flow tube. The 9,10-anthraquinone desorption curves for both reactors are presented 
in Fig. 1. Each point represents the average of 3 replicates and the error bars correspond to \pm 1 standard deviation. As losses due to desorption were not significantly different from zero, they were considered as negligible.

\subsection{Heterogeneous ozone reaction}

Heterogeneous reactions of ozone with 9,10-anthraquinone were carried out with a high $\mathrm{O}_{3}$ concentration $\left(5.4 \times 10^{14}\right.$ molecule $\left.\mathrm{cm}^{-3}\right)$ for two exposure times: 1800 and $3600 \mathrm{~s}$. As presented on Fig. 1, the loss of 9,10-anthraquinone with $\mathrm{O}_{3}$ could not be separated from that obtained for desorption experiments within uncertainties, whatever the exposure time. The ozone concentration used in this work is very higher than the mean values encountered in the troposphere: 0.5 to $1 \times 10^{12}$ molecule $\mathrm{cm}^{-3}$ in the northern hemisphere (Vingarzan, 2004), even in high polluted locations with concentrations reaching $4.5 \times 10^{12}$ molecule $\mathrm{cm}^{-3}$ (European Environment Agency, 2006). The high stability of 9,10-anthraquinone adsorbed on silica particles with ozone shows that this way cannot be involved in 9,10 -anthraquinone atmospheric degradation processes.

These results confirm those of Grosjean et al. (1987), which were unable to detect any loss of 9,10-anthraquinone coated on Teflon, cellulose or silica gel exposed to ozone (about $2.5 \times 10^{14}$ molecule $\mathrm{cm}^{-3}$ ) during 18 to 80 hours in the absence of light. Perraudin et al. (2007b) observed that the reaction between anthracene adsorbed on silica particles with ozone led to the formation of 9,10-anthraquinone. Once it was formed, 9,10-anthraquinone seemed to reach a plateau and thus not react with ozone, showing that this compound was stable to ozone exposure. Only Ringuet et al. (2012b) observed a slight degradation of 9,10anthraquinone associated to natural ambient aerosol and exposed to high concentrations of ozone (about $1 \times 10^{14}$ molecule $\mathrm{cm}^{-3}$ ). As showed by different authors ((Nguyen et al., 2009; 
Bedjanian et al., 2010; Ringuet et al., 2012b)), the particle substrate (silica vs "real" particle) could play a role in the degradation processes.

\subsection{Heterogeneous $\mathrm{NO}_{2}$ reaction}

The exposure of 9,10-anthraquinone adsorbed on silica particles to $\mathrm{NO}_{2}$ showed the absence of reactivity, as presented on Fig. 1, despite the $\mathrm{NO}_{2}$ concentration used in this work: $2.7 \times 10^{14}$ molecule $\mathrm{cm}^{-3}$. This concentration is much higher than those measured in polluted areas such as Mexico City with concentrations reaching $3 \times 10^{12}$ molecule $\mathrm{cm}^{-3}$ (Dunlea et al., 2007) demonstrates that 9,10-anthraquinone will not react in the atmosphere with $\mathrm{NO}_{2}$, and thus that $\mathrm{NO}_{2}$ reactions are not involved in 9,10-anthraquinone degradation in the atmosphere. These results are in total agreement with the observations made recently by Ringuet et al. (2012b) for 9,10-anthraquinone (and other quinones) associated to natural ambient particles exposed to $\mathrm{O}_{3}$ and $\mathrm{NO}_{2}$ in similar conditions than ours $\left(\mathrm{O}_{3}\right.$ and $\mathrm{NO}_{2}$ concentrations about $1 \times$ $10^{14}$ molecule $\left.\mathrm{cm}^{-3}\right)$.

\subsection{Heterogeneous $\mathrm{OH}$ reaction}

Contrary to heterogeneous $\mathrm{O}_{3}$ and $\mathrm{NO}_{2}$ reactions, 9,10-anthraquinone was degraded by $\mathrm{OH}$ reactions in the presence of $\mathrm{NO}_{2}\left(2.7 \times 10^{13}\right.$ molecule $\left.\mathrm{cm}^{-3}\right)$. These results are also in agreement with those reported for 9,10-anthraquinone associated to "real" ambient particle (Ringuet et al., 2012b). If here, the degradation of 9,10-anthraquinone was total, in the case of the study of Ringuet et al. (2012b), only about $30 \%$ was degraded after 60 minutes of exposure to similar $\mathrm{OH}$ concentration levels. The influence of the nature of the substrate and compound accessibility could explain the differences observed between these studies. 
The kinetics of this reaction was investigated by monitoring normalised concentrations of 9,10-anthraquinone as a function of $\mathrm{He} / \mathrm{OH} / \mathrm{NO}_{2} / \mathrm{NO}$ exposure time. A complete degradation was observed after a sufficient exposure time to $\left(\mathrm{OH}+\mathrm{NO}_{2}\right)$ (no more 9,10-anthraquinone was detected), meaning that the reaction between the oxidants and 9,10-anthraquinone was total. Experimental data points, presented in Fig. 1, were fitted by a simple mono-exponential function using non linear least square fitting, allowing to determine a pseudo-first-order rate constant: $(2.8 \pm 0.7) \times 10^{-3} \mathrm{~s}^{-1}$ for the $\left(\mathrm{OH}+\mathrm{NO}_{2}\right)$ reaction with 9,10 -anthraquinone adsorbed on silica particles. Previous experiments performed in this work showed that heterogeneous $\mathrm{NO}_{2}$ reactivity with 9,10-anthraquinone was negligible. Thus, the pseudo-first order rate constant determined for $\left(\mathrm{OH}+\mathrm{NO}_{2}\right)$ reactivity can be attributed to that of $\mathrm{OH}$ alone.

It is important to note that the pseudo-first order rate constant for the $(\mathrm{OH}+9,10$ anthraquinone) reaction was derived at a higher $\mathrm{OH}$ concentration than the typical ambient concentrations $\left(\sim 10^{5}-10^{6}\right.$ molecule $\left.\mathrm{cm}^{-3}\right)$ and therefore would not be logically applicable to the atmospheric conditions. Although the $\mathrm{OH}$ radical concentrations could not be measured in this study, a rough estimation of the $\mathrm{OH}$ radical concentrations may provide some atmospherically relevant information. In a previous work carried out by our group (Estève et al., 2003), the $\mathrm{OH}$ radical concentration measured in the same conditions was $[\mathrm{OH}]=3.4 \times$ $10^{10}$ molecule $\mathrm{cm}^{-3}$. Considering that this concentration is similar to that obtained in this work, the second-order rate constant for the $\mathrm{OH}+9,10$-anthraquinone reaction would be $8.2 \times$ $10^{-14} \mathrm{~cm}^{3}$ molecule $\mathrm{s}^{-1}$. With typical $\mathrm{OH}$ concentrations in ambient air, the lifetime of 9,10anthraquinone by the heterogeneous reaction with $\mathrm{OH}$ radicals would be 140 - 1400 days. This lifetime seems to be relatively long, but its determination has to be taken with caution. The $\mathrm{OH}$ concentration used to calculate the lifetime is a possible value measured previously with the same experimental setup, but with a another helium bottle. Due to the way of $\mathrm{OH}$ production (fast reaction between $\mathrm{NO}_{2}$ and a $\mathrm{H}$ atom, produced by hydrogen impurities from a 
helium bottle), it is possible that the bottle used in this work contained less (or more) hydrogen impurities than that used by Estève et al. (2003). Thus the real $\mathrm{OH}$ concentration available to 9,10-anthraquinone adsorbed to particles could be smaller (or more important) and the lifetime shorter (or longer). However this work shows for the first time that $\mathrm{OH}$ radicals can react with 9,10-anthraquinone in the particulate-phase, showing that $\mathrm{OH}$ can be involved in 9,10-anthraquinone degradation processes.

\subsection{Oxidation product study}

The investigation of oxidation products was carried out by GC-MS in the scan mode (mass/charge ratio ranging from 50 to 550 and number of scans per second $=1.53$ ). The chromatograms showed only one peak from the oxidation 9,10-anthraquinone adsorbed on silica particles with $\left(\mathrm{OH}+\mathrm{NO}_{2}\right)$. Its mass spectrum (Fig. 2) was compared to that obtained from the library mass spectra (NIST 98, HP Mass Spectral Libraries, 1998), allowing to identify 1-hydroxy-9,10-anthraquinone. The comparison of its retention time with that of a standard confirmed that this oxidation product was 1-hydroxy-9,10-anthraquinone. This compound was the only product identified, and thus neither a nitrated nor another hydroxylated oxidation product was identified in the extract. The formation of 1-hydroxy9,10-anthraquinone is also important because it confirms that $\mathrm{OH}$ radicals have reacted with 9,10-anthraquinone adsorbed on silica particles (addition of $\mathrm{OH}$ to 9,10-anthraquinone).

To our knowledge, 1-hydroxy-9,10-anthraquinone has never been identified as an oxidation product from $(9,10$-anthraquinone $+\mathrm{OH})$ of atmospheric interest. However, the formation of this compound was observed by several studies. Lehto et al. (2003) observed the formation of 1-hydroxy-9,10-anthraquinone after UV-irradiation in the presence of oxygen during $51 \mathrm{~h}$ of a saturated solution of 9,10-anthraquinone, probably implying the formation of 
hydroxyl radical. 1,4-Dihydroxy-9,10-anthraquinone was also characterized as a product from 1-hydroxy-9,10-anthraquinone. These oxidation products were also observed by Mallakin et al. (2000) with the formation of other oxidation products. Fox and Olive (1979) reported also the formation of 1-hydroxy-9,10-anthraquinone during the photooxidation of anthracene associated to atmospheric particulate matter (which led also to the formation of 9,10anthraquinone).

In this work, only 1-hydroxy-9,10-anthraquinone was determined but this oxidation product could have a health impact and account for global 9,10-anthraquinone toxicity, since it is also recognized as possibly carcinogenic to humans (Group 2B) (IARC, 2002), 1Hydroxy-9,10-anthraquinone disappearance after all 9,10-anthraquinone degradation demonstrates that other oxidation products must be formed. More investigations will be performed to improve the analytical procedure in order to complete oxidation products determination, and thus better understand oxidation mechanisms involved in this reaction.

\section{Conclusions}

In this work, the heterogeneous chemical oxidation of the carcinogenic 9,10anthraquinone has been investigated in order to evaluate its atmospheric fate in the particulate-phase. 9,10-Anthraquinone adsorbed on silica particles was exposed to ozone, nitrogen dioxide and hydroxyl radical in the darkness. Such experiments highlight the high stability of 9,10-Anthraquinone to $\mathrm{O}_{3}$ and $\mathrm{NO}_{2}$ exposures, when $\mathrm{OH}$ radicals seems to account as a possible 9,10-Anthraquinone degradation process in the atmosphere. 1-Hydroxy-9,10anthraquinone, another compound possibly carcinogen to humans, has been detected as an oxidation product from the heterogeneous $\mathrm{OH}$ reaction, demonstrating that $(9,10-$ anthraquinone $+\mathrm{OH}$ ) reaction could have an atmospheric health impact. 
This work shows for the first time that $\mathrm{O}_{3}$ and $\mathrm{NO}_{2}$ are not involved in 9,10-anthraquinone degradation, when $\mathrm{OH}$ may play an important role. However, other oxidation processes are probably involved in 9,10-anthraquinone degradation. Thus, more investigations need to be performed in order to complete and better understand 9,10-anthraquinone fate in the atmosphere. For example, it could be interesting to better document 9,10-anthraquinone photodegradation. A previous study performed by Kamens et al. (1989) observed that 9,10anthraquinone adsorbed on soot particles was stable to midday sunlight exposure, but other works showed that 9,10-anthraquinone could be degraded by UV-irradiation (Fox and Olive, 1979; Mallakin et al., 2000; Lehto et al., 2003). These observations highlight that photooxidation could be an important degradation process for 9,10 -anthraquinone degradation in the atmosphere. 


\section{Acknowledgements}

The authors wish to thank the French National Research Agency, the Aquitaine Region and the PRIMEQUAL 2 Programme of the French Ministry of Ecology and Sustainable Development for financial support.

\section{References}

Albinet, A., Leoz-Garziandia, E., Budzinski, H., Villenave, E., 2006. Simultaneous analysis of oxygenated and nitrated polycyclic aromatic hydrocarbons on standard reference material 1649a (urban dust) and on natural ambient air samples by gas chromatographymass spectrometry with negative ion chemical ionisation. J. Chromatogr. A 1121, 106113.

Albinet, A., Leoz-Garziandia, E., Budzinski, H., Villenave, E., 2007. Polycyclic aromatic hydrocarbons (PAHs), nitrated PAHs and oxygenated PAHs in ambient air of the Marseilles area (South of France): Concentrations and sources. Sci. Total Environ. 384, 280-292.

Albinet, A., Leoz-Garziandia, E., Budzinski, H., Villenave, E., Jaffrezo, J.L., 2008. Nitrated and oxygenated derivatives of polycyclic aromatic hydrocarbons in the ambient air of two French alpine valleys. Part 1: Concentrations, sources and gas/particle partitioning. Atmos. Environ. 42, 43-54.

Alebic-Juretic, A., Cvitas, T., Klasinc, L., 1990. Heterogeneous polycyclic aromatic hydrocarbon degradation with ozone on silica gel carrier. Environ. Sci. Technol. 24, 6266. 
Allen, J.O., Dookeran, N.M., Taghizadeh, K., Lafleur, A.L., Smith, K.A., Sarofim, A.F., 1997. Measurement of oxygenated polycyclic aromatic hydrocarbons associated with a size-segregated urban aerosol. Environ. Sci. Technol. 31, 2064-2070.

Andreou, G., Rapsomanikis, S., 2009. Polycyclic aromatic hydrocarbons and their oxygenated derivatives in the urban atmosphere of Athens. J. Hazard. Mater. 172, 363-373.

Atkinson, R., Arey, J., 2007. Mechanisms of the gas-phase reactions of aromatic hydrocarbons and PAHs with $\mathrm{OH}$ and $\mathrm{NO}_{3}$ radicals. Polycycl. Aromat. Comp. 27, 15-40.

Barbas, J.T., Sigman, M.E., Dabestani, R., 1996. Photochemical oxidation of phenanthrene sorbed on silica gel. Environ. Sci. Technol. 30, 1776-1780.

Bedjanian, Y., Nguyen, M.L., Le Bras, G., 2010. Kinetics of the reactions of soot surfacebound polycyclic aromatic hydrocarbons with the OH radicals. Atmos. Environ. 44, 17541760.

Behymer, T.D., Hites, R.A., 1985. Photolysis of polycyclic aromatic hydrocarbons adsorbed on simulated atmospheric particulates. Environ. Sci. Technol.19, 1004-1006.

Brigante, M., Cazoir, D., D’Anna, B., George, C., Donaldson, D.J., 2008. Photoenhanced uptake of $\mathrm{NO}_{2}$ by pyrene solide films. J. Phys. Chem. A 112, 9503-9508.

Callén, M.S., de la Cruz, M.T., López, J.M., Murillo, R., Navarro, M.V., Mastral, A.M., 2008. Some inferences on the mechanism of atmospheric gas/particle partitioning of polycyclic aromatic hydrocarbons (PAH) at Zaragoza (Spain). Chemosphere 73, $1357-$ 1365.

Castells, P., Santos, F.J., Galceran, M.T., 2003. Development of a sequential supercritical fluid extraction method for the analysis of nitrated and oxygenated derivatives of polycyclic aromatic hydrocarbons in urban aerosols. J. Chromatogr. A 1010, 141-151. 
Chesis, P.L., Levin, D.E., Smith, M.T., Ernster, L., Ames, B.N., 1984. Mutagenicity of quinones: Pathways of metabolic activation and detoxification. Proceedings of the National Academy of Sciences of the United States of America 81, 1696-1700.

Cho, A.K., Di Stefano, E., You, Y., Rodriguez, C.E., Schmitz, D.A., Kumagai, Y., Miguel, A.H., Eiguren-Fernandez, A., Kobayashi, T., Avol, E., Froines, J.R., 2004. Determination of four quinones in diesel exhaust particles, SRM 1649a, and atmospheric PM2.5. Aerosol Sci. Tech. 38, 68-81.

Dabestani, R., Ellis, K.J., Sigman, M.E., 1995. Photodecomposition of anthracene on dry surfaces: products and mechanism. J. Photoch. Photobio. A 86, 231-239.

Del Rosario Sienra, M., Rosazza, N.G., 2006. Occurrence of nitro-polycyclic aromatic hydrocarbons in urban particulate matter PM10. Atmos. Res. 81, 265-276.

Dunlea, E.J. , Herndon, S.C., Nelson, D.D., Volkamer, R.M., San Martini, F., Sheehy, P.M., Zahniser, M.S., Shorter, J.H., Wormhoudt, J.C., Lamb, B.K., Allwine, E.J., Gaffney, J.S., Marley, N.A., Grutter, M., Marquez, C., Blanco, S., Cardenas, B., Retama, A., Ramos Villegas, C.R., Kolb, C.E., Molina, L.T., Molina, M.J., 2007. Evaluation of nitrogen dioxide chemiluminescence monitors in a polluted urban environment. Atmos. Chem. Phys. 7, 2691-2704.

Durant, J.L., Busby Jr, W.F., Lafleur, A.L., Penman, B.W., Crespi, C.L., 1996. Human cell mutagenicity of oxygenated, nitrated and unsubstituted polycyclic aromatic hydrocarbons associated with urban aerosols. Mut. Res. - Genet. Tox. 371, 123-157.

Durant, J.L., Lafleur, A.L., Plummer, E.F., Taghizadeh, K., Busby, W.F., Thilly, W.G., 1998. Human lymphoblast mutagens in urban airborne particles. Environ. Sci. Technol. 32, 1894-1906.

Estève, W., Budzinski, H., Villenave, E., 2003. Heterogeneous reactivity of OH radicals with phenanthrene. Polycycl. Aromat. Comp. 23, 441-456. 
Estève, W., Budzinski, H., Villenave, E., 2004. Relative rate constants for the heterogeneous reactions of $\mathrm{OH}, \mathrm{NO}_{2}$ and $\mathrm{NO}$ radicals with polycyclic aromatic hydrocarbons adsorbed on carbonaceous particles. Part 1: PAHs adsorbed on 1-2 $\mu \mathrm{m}$ calibrated graphite particles. Atmos. Environ. 38, 6063-6072.

European Environment Agency, 2006. Air pollution by ozone in Europe in summer 2005. EEA Technical Report $\mathbf{n}^{\circ} 3$.

Fox, M.A., Olive, S., 1979. Photooxidation of anthracene on atmospheric particulate matter. Science 205, 582-583.

Grosjean, D., Whitmore, P.M., De Moor, C.P., Cass, G.R., Druzik, J.R., 1987. Fading of alizarin and related artists' pigments by atmospheric ozone: reaction products and mechanisms. Environ. Sci. Technol. 21, 635-643.

Gross, S., Bertram, A.K., 2008. Reactive uptake of $\mathrm{NO}_{3}, \mathrm{~N}_{2} \mathrm{O}_{5}, \mathrm{NO}_{2}, \mathrm{HNO}_{3}$, and $\mathrm{O}_{3}$ on three types of polycyclic aromatic hydrocarbon surfaces. J. Phys. Chem. A 112, 3104-3113.

Harrison, R.M., Yin, J., 2000. Particulate Matter in the atmosphere: which particle properties are important for its effects on health? Sci. Total Environ. 249, 85-101.

Helmig, D., Harger, W.P., 1994. OH radical-initiated gas-phase reaction products of phenanthrene. Sci. Total Environ. 148, 11-21.

IARC, 2002. Some Traditional Herbal Medicines, Some Mycotoxins, Naphthalene and styrene. Monographs on the evaluation of the carcinogenic risk of chemicals to humans, vol. 82. International Agency for Research on Cancer, Lyon.

IARC, 2012. A review of human carcinogens: Some chemicals in industrial and consumer products, food contaminants and flavourings, and water chlorination by-products, Lyon.

Jakober, C.A., Charles, M.J., Kleeman, M.J., Green, P.G., 2006. LC-MS analysis of carbonyl compounds and their occurrence in diesel emissions. Anal. Chem. 78, 5086-5093. 
Kamens, R.M., Karam, H., Guo, J., Perry, J.M., Stockburger, L., 1989. The behavior of oxygenated polycyclic aromatic hydrocarbons on atmospheric soot particles. Environ. Sci. Technol. 23, 801-806.

König, J., Balfanz, E., Funcke, W., Romanowski, T., 1983. Determination of oxygenated polycyclic aromatic hydrocarbons in airborne particulate matter by capillary gas chromatography and gas chromatography/mass spectrometry. Anal. Chem. 55, 599-603.

Kumagai, Y., Shimojo, N., 2001. Induction of oxidative stress and dysfunction of nitric oxidedependent vascular tone caused by quinones contained in diesel exhaust particles. J. Health Sci. 47, 439-445.

Kwamena, N.O.A., Earp, M.E., Young, C.J., Abbatt, J.P.D., 2006. Kinetic and product yield study of the heterogeneous gas-surface reaction of anthracene and ozone. J. Phys. Chem. A $110,3638-3646$.

Lehto, K.M., Puhakka, J.A., Lemmetyinen, H., 2003. Photodegradation products of polycyclic aromatic hydrocarbons in water and their amenability to biodegradation. Polycycl. Aromat. Comp. 23, 401-416.

Lemaire, P., Livingstone, D.R., 1997. Aromatic hydrocarbon quinone-mediated reactive oxygen species production in hepatic microsomes of the flounder (Platichthys flesus L.). Comp. Biochem. Physiol. 117C, 131-139.

Lewis, A.C., Robinson, R.E., Bartle, K.D., Pilling, M.I., 1995. On-line coupled LC-GCITD/MS for the identification of alkylated, oxygenated, and nitrated polycyclic aromatic compounds in urban air particulate extracts. Environ. Sci. Technol. 29, 1977-1981.

Liberman, D.F., Fink, R.C., Schaefer, F.L., Mulcahy, R.J., Stark, A.A., 1982. Mutagenicity of anthraquinone and hydroxylated anthraquinones in the ames/salmonella microsome system. Appl. Environ. Microb. 43, 1354-1359. 
Mallakin, A., George Dixon, D., Greenberg, B.M., 2000. Pathway of anthracene modification under simulated solar radiation. Chemosphere 40, 1435-1441.

Miet, K., Le Menach, K., Flaud, P.M., Budzinski, H., Villenave, E., 2009a. Heterogeneous reactivity of pyrene and 1-nitropyrene with $\mathrm{NO}_{2}$ : Kinetics, product yields and mechanism. Atmos. Environ. 43, 837-843.

Miet, K., Le Menach, K., Flaud, P.M., Budzinski, H., Villenave, E., 2009b. Heterogeneous reactions of ozone with pyrene, 1-hydroxypyrene and 1-nitropyrene adsorbed on particles. Atmos. Environ. 43, 3699-3707.

Miet, K., Budzinski, H., Villenave, E., 2009c. Heterogeneous reactions of OH radicals with particulate-pyrene and 1-nitropyrene of atmospheric interest. Polycycl. Aromat. Comp. $29,267-281$.

Nguyen, M., Bedjanian, Y., Guilloteau, A., 2009. Kinetics of the reactions of soot surfacebound polycyclic aromatic hydrocarbons with $\mathrm{NO}_{2}$. J. Atmos. Chem. 62, 139-150.

Odabasi, M., Vardar, N., Sofuoglu, A., Tasdemir, Y., Holse, T.M., 1999. Polycyclic Aromatic Hydrocarbons (PAHs) in Chicago air. Sci. Total Environ. 227, 57-67.

Pedersen, D.U., Durant, J.L., Penman, B.W., Crespi, C.L., Hemond, H.F., Lafleur, A.L., Cass, G.R., 2004. Human-cell mutagens in respirable airborne particles in the northeastern United States. 1. Mutagenicity of fractionated samples. Environ. Sci. Technol. 38, 682689.

Pedersen, D.U., Durant, J.L., Taghizadeh, K., Hemond, H.F., Lafleur, A.L., Cass, G.R., 2005. Human cell mutagens in respirable airborne particles from the Northeastern United States. 2. Quantification of mutagens and other organic compounds. Environ. Sci. Technol. 39, $9547-9560$. 
Perraudin, E., Budzinski, H., Villenave, E., 2005. Kinetic study of the reactions of $\mathrm{NO}_{2}$ with polycyclic aromatic hydrocarbons adsorbed on silica particles. Atmos. Environ. 39, 65576567.

Perraudin, E., Budzinski, H., Villenave, E., 2007a. Kinetic study of the reactions of ozone with polycyclic aromatic hydrocarbons adsorbed on atmospheric model particles. J. Atmos. Chem. 56, 57-82.

Perraudin, E., Budzinski, H., Villenave, E., 2007b. Identification and quantification of ozonation products of anthracene and phenanthrene adsorbed on silica particles. Atmos. Environ. 41, 6005-6017.

Pitts, J.N. Jr., Sweetman, J.A., Zielinska, B., Atkinson, R., Winer, A.M., Harger, W.P., 1985. Formation of nitroarenes from the reaction of polycyclic aromatic hydrocarbons with dinitrogen pentaoxide. Environ. Sci. Technol. 19, 1115-1121.

Ringuet, J., Albinet, A., Leoz-Garziandia, E., Budzinski, H., Villenave, E., 2012a. Diurnal/nocturnal concentrations and sources of particulate-bound PAHs, OPAHs and NPAHs at traffic and suburban sites in the region of Paris (France). Sci. Total Environ., 437, 297-305.

Ringuet, J., Albinet, A., Leoz-Garziandia, E., Budzinski, H., Villenave, E., 2012b. Reactivity of polycyclic aromatic compounds (PAHs, NPAHs and OPAHs) adsorbed on natural aerosol particles exposed to atmospheric oxidants. Atmos. Environ., 61, 15-22.

Rodriguez, I., Gali, S., Marcos, C., 2008. Atmospheric inorganic aerosol of a non-industrial city in the centre of an industrial region of the north of Spain, and its possible influence on the climate on a regional scale. Environ. Geol. 56, 1551-1561.

Shimmo, M., Anttila, P., Hartonen, K., Hyotylainen, T., Paatero, J., Kulmala, M., Riekkola, M.L., 2004. Identification of organic compounds in atmospheric aerosol particles by on- 
line supercritical fluid extraction-liquid chromatography-gas chromatography-mass pectrometry. J. Chromatogr. A 1022, 151-159.

Styler, S.A., Brigante, M., D’Anna, B., George, C., Donaldson, D.J., 2009. Photoenhanced ozone loss on solid pyrene films. Phys. Chem. Chem. Phys. 36, 7876-7884.

Vingarzan, R., 2004. A review of surface ozone background levels and trends. Atmos. Environ. 38, 3431-3442.

Vione, D., Barra, S., De Gennaro, G., De Rienzo, M., Gilardoni, S., Perrone, M.G., Pozzoli, L., 2004. Polycyclic aromatic hydrocarbons in the atmosphere: monitoring, sources, sinks and fate. II: Sinks and fate. Ann. Chim. 94, 257-268.

Wang, H., Hasegawa, K., Kagaya, S., 1999. Nitration of pyrene adsorbed on silica particles by nitrogen dioxide under simulated atmospheric conditions. Chemosphere 39, 1923 1936.

Wang, L., Atkinson, R., Arey, J., 2007. Formation of 9,10-phenanthrenequinone by atmospheric gas-phase reactions of phenanthrene. Atmos. Environ. 41, 2025-2035.

Yu, H., 2002. Environmental carcinogenic polycyclic aromatic hydrocarbons: photochemistry and phototoxicity. J. Environ. Sci. Health., Part C 20, 149-183. 


\section{Figure captions}

Fig. 1. Experimental decay corresponding to the normalised concentration of 9,10anthraquinone adsorbed on silica particles as a function of exposure time to $\mathrm{O}_{3}$ (white circles: loss by desorption; black circles: loss by $\mathrm{O}_{3}$ reaction for $\left[\mathrm{O}_{3}\right]=5.4 \times 10^{14}$ molecule $\mathrm{cm}^{-3}$ ), $\mathrm{NO}_{2}$ (white triangles: loss by desorption; white circles: loss by $\mathrm{NO}_{2}$ reaction for $\left[\mathrm{NO}_{2}\right]=2.7 \times 10^{14}$ molecule $\mathrm{cm}^{-3}$ ) and to $\mathrm{OH}$ (inversed black triangles: loss by $\mathrm{OH}$ reaction). Error bars represent 1 standard deviation $(\mathrm{n}=3)$.

Fig. 2. Mass spectrum of 1-hydroxy-9,10-anthraquinone as a product from the heterogeneous reaction of $\left(\mathrm{OH}+\mathrm{NO}_{2}\right)$ with 9,10 -anthraquinone adsorbed on silica particles. 


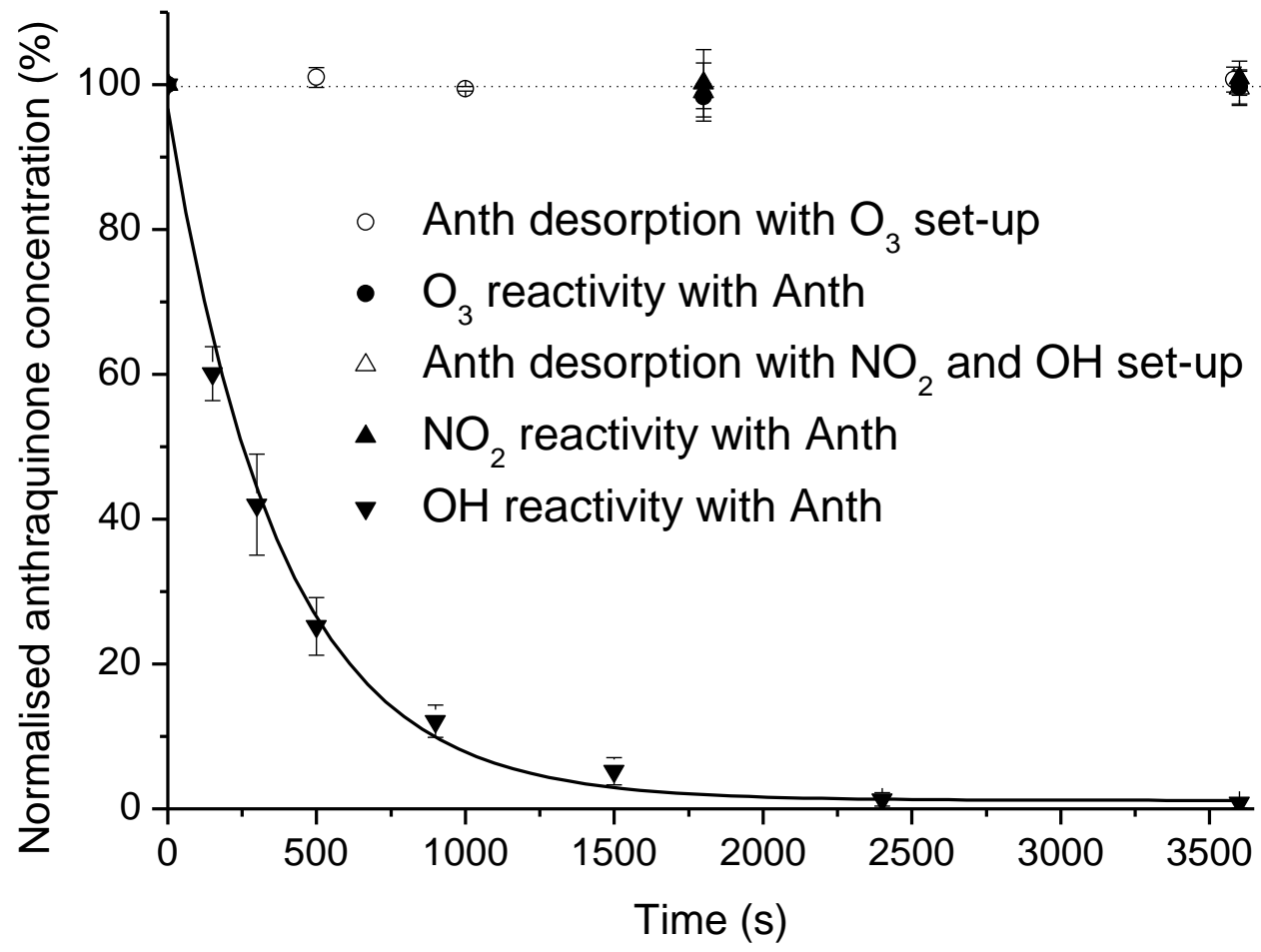

Fig. 1. Experimental decay corresponding to the normalised concentration of 9,10anthraquinone (Anth) adsorbed on silica particles as a function of exposure time to $\mathrm{O}_{3}$ (white circles: loss by desorption; black circles: loss by $\mathrm{O}_{3}$ reaction for $\left[\mathrm{O}_{3}\right]=5.4 \times 10^{14}$ molecule $\mathrm{cm}^{-3}$ ), $\mathrm{NO}_{2}$ (white triangles: loss by desorption; white circles: loss by $\mathrm{NO}_{2}$ reaction for $\left[\mathrm{NO}_{2}\right]$ $=2.7 \times 10^{14}$ molecule $\mathrm{cm}^{-3}$ ) and to $\mathrm{OH}$ (inversed black triangles: loss by $\mathrm{OH}$ reaction). Error bars represent 1 standard deviation $(n=3)$. 


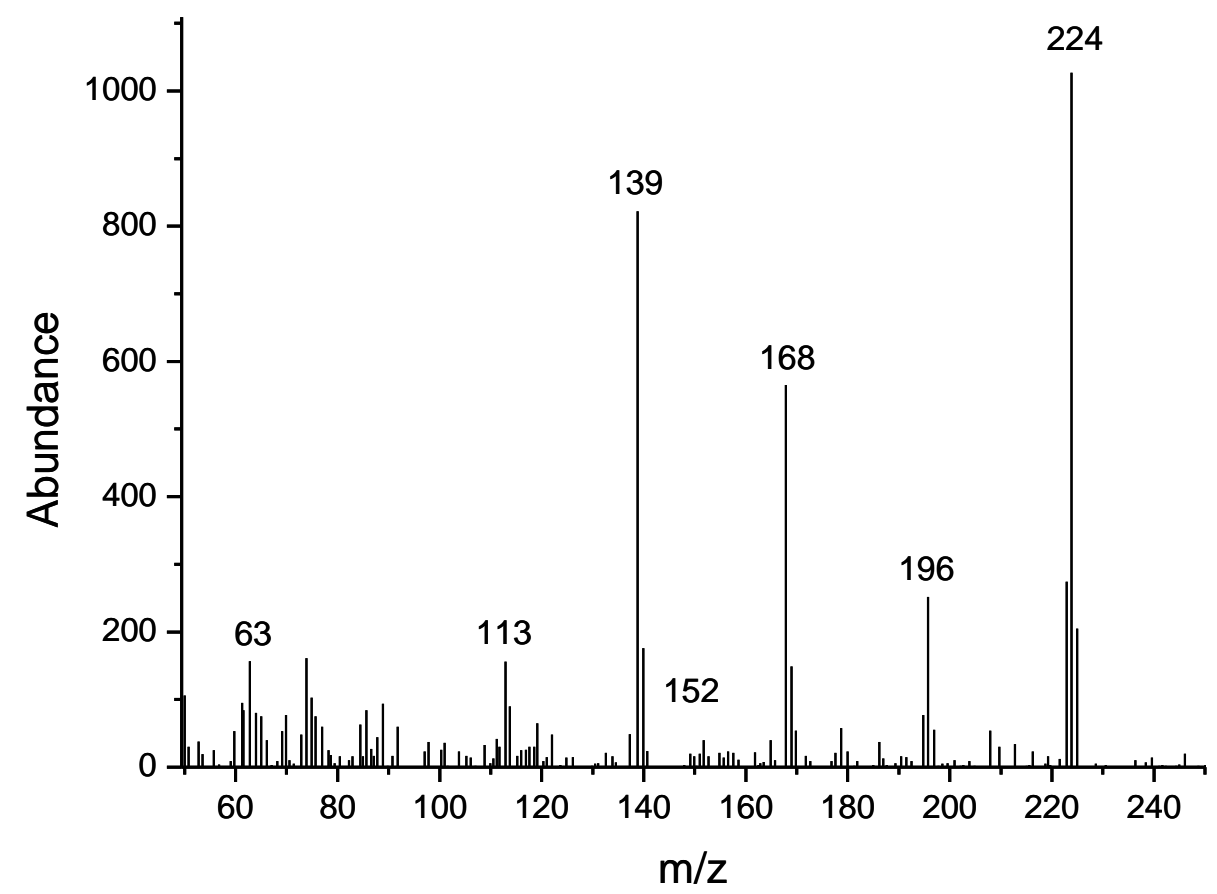

Fig. 2. Mass spectrum of 1-hydroxy-9,10-anthraquinone as a product from the heterogeneous reaction of $\mathrm{OH}$ with 9,10-anthraquinone adsorbed on silica particles. 